of computer science]: Zhytomyr. 614 s. [in Ukrainian].

Khmarni servisy Office 365 [Office 365 cloud services]. (2015) / za red. S. H. Lytvynova. Kyiv: Komprynt. 170 c. [in Ukrainian].

Serohodskyy, V. V., Tykhomyrov, A. P., Suryn, D. P. (2017). Microsoft Office 2016/Office 365. Khar'kov: Nauka y tekhnyka. 448 s. [in Russian].

Krutous, T. P. (2019). Formuvannya matematychnoyi kompetentnosti u studentiv ekonomichnykh spetsial'nostey zasobamy IKT tekhnolohiy [Formation of mathematical competence in students of economic specialties by means of ICT technologies]. Fizyko-matematychna osvita. Sumy: Sums'kyy derz. ped. un-t imeni A. S. Makarenka. № 4 (22). S. 75-78. [in Ukrainian].

Royko, L. L., Royko, O. O. (2018). Prykladna spryamovanist' kursu «Matematyka dlya ekonomistiv ta ekonomichne modelyuvannya» [Applied orientation of the course
Mathematics for economists and economic modeling]. Komp'yuterno-intehrovani tekhnolohiyi: osvita, nauka, vyrobnytstvo. Luts'k: LNTU. № 30/31. S. 263-268. [in Ukrainian].

Stepanova, N. I. (2008). Rozv'yazannya ekonomichnykh zadach zasobamy Microsoft Excel: praktykum[Solve economic problems with Microsoft Excel]. Dnipropetrovs'k: DNU. 68 s. [in Ukrainian].

Tataurov, V. P., Shyshkina, M. P. (2020). Metodyka vykorystannya servisiv Microsoft Office 365 dlya pidtrymuvannya spil'noyi roboty studentiv [Methods of using Microsoft Office 365 services to support student collaboration]. Fizyko-matematychna osvita. Sumy: Sums'kyy derz. ped. un-t imeni A. S. Makarenka. № 2 (24). S. 151-158. [in Ukrainian].

Дата надходження до редакиї: 07.02.2021 p.
УДК 378.14

DOI: $10.37026 / 2520-6427-2021-105-1-35-42$

\author{
Валерій КРІВЦОВ, \\ кандидат технічних наук, \\ доцент кафедри теоретичної механіки, \\ інженерної графіки та машинознавства \\ Національного університету водного \\ господарства та природокористування, \\ м. Рівне, Україна \\ ORCD: 0000-0002-7233-1891 \\ e-mail:v.v.krivtsov@nuwm.edu.ua
}

\section{Валентин КРІВЦОВ,}

кандидат фізико-математичних наук, доиент кафедри фізики, астрономії та методики викладання Рівненського державного гуманітарного університету, м. Рівне, Украӥна ORCID: 0000-0002-8338-645X

e-mail:valek.krivtsov@gmail.com

\title{
ДИСТРАКТОРНИЙ АНАЛІЗ ТЕСТОВИХ ЗАВДАНЬ ЯК ЗАСІБ ПІДВИЩЕННЯ ЇХНЬОЇ ЯКОСТІ В ТЕХНІЧНИХ ЗАКЛАДАХ ВИЩОЇ ОСВІТИ
}

\begin{abstract}
Анотація. Вважасться, щуо основним завданням, яке ставиться перед тестуванням, - диференціювати здобувачів освіти за кількістю балів, набраних під час відповідей на представлені тестові завдання. Проте на сучасному етапі розвитку освіти, зокрема і вищої, вимоги до тестів значно розширилися. Крім основної функиї - контролюючої, додаються ще дві - освітня та розвиваюча. Означені функиії будуть ефективними лите за умови застосування якісно складеного тесту, який об'єктивно відображатиме навчальні досягнення. Якісний тест неможливо підготувати з першого разу, без попередньої тестової апробації, спрямованої на виявлення тих завдань, які не виконують покладених на них функиій. Методи математично-статистичної об-
\end{abstract}

робки результатів тестування, щзо застосовуються як у класичній, так і сучасній теорії тестів, дозволяють виявляти ті завдання, зміст яких потребує корегування. Тестові завдання складаються з правильних відповідей та дистракторів - неправильних, але правдоподібних відповідей, тому наступним кроком у процесі створення якісного тесту стає аналіз змісту тих дистракторів, які привертають до себе найбільшу та найменшу увагу осіб, які підлягають тестуванню. Це дозволить оиінити привабливість дистракторів та змінити їхній зміст на більш ефективно діючий.

Ключові слова: тестові завдання, дистракторний аналіз, дискримінативність, нарисна геометрія, корекція тестових завдань. 


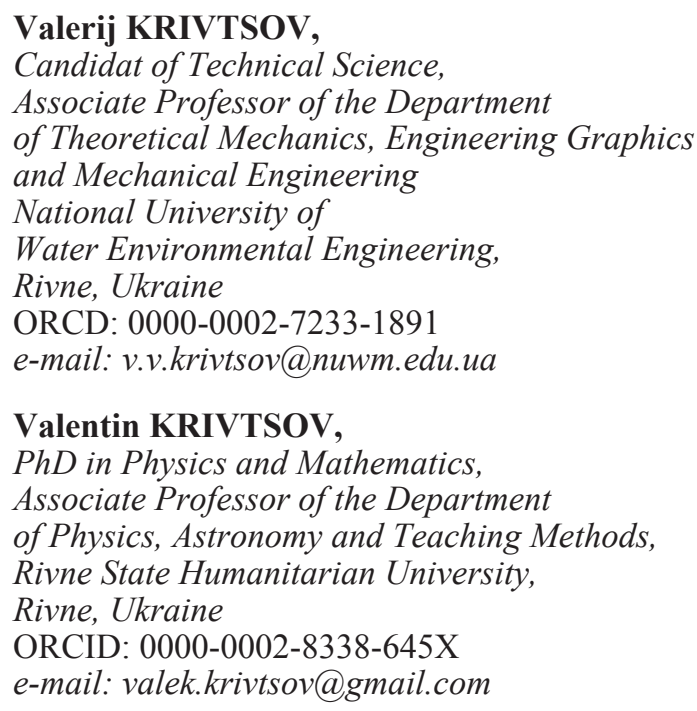

\section{DISTRACTOR ANALYSIS OF TEST TASKS AS A METHOD OF IMPROVING THEIR QUALITY IN HIGHER EDUCATIONAL INSTITUTIONS}

\begin{abstract}
It is believed that the main task facing testing is differentiating education seekers by the number of points scored while answering test tasks. However, nowadays the requirements for tests have expanded significantly. In addition to the main, controlling function, educational and developing ones are added. All these functions will only work effectively if a well-designed test is used that objectively reflects educational achievements. A quality test cannot be prepared the first time without preliminary test approbation, the purpose of which is to identify those tasks that do not fulfill the functions assigned to them. Methods of mathematical and statistical processing of test results, which are used in both classical and modern theory of tests, make it possible to identify those tasks, the content of which will require correction. Test tasks consist of correct answers and distractors. Therefore, the next step in the process of creating a quality test is to analyze the content of those distractors that attract the most and least attention of the tested people. This allows us to assess the attractiveness of distractors and change their content to a more efficient one. Such distractors should help to comprehend and generalize the educational material, identify gaps in its assimilation and facilitate the analysis of the results obtained. It is the Ignoring of the need for distractor analysis that is one of the reasons for the lack of quality tests. Another reason is the small number of publications on the results of distractor analysis.

The purpose of this article is to show, with specific examples, how to carry out distractor analysis of test tasks to identify efficiently working distractors, as well as those distractors that most of the tested students perceive as clearly implausible and which must be replaced.

Key words: test tasks, distractor analysis, discriminativeness, descriptive geometry, correction of test tasks.
\end{abstract}

Постановка проблеми. В сучасному освітньому просторі перевірка знань, умінь та навичок здобувачів освіти здійснюється за допомогою тестових методів.
Оцінювання програмних результатів навчання повинно бути об'єктивним, а самі тестові завдання, окрім контролюючої ролі, повинні сприяти оволодінню навчальним матеріалом, допомагати його осмисленню, узагальненню та аналізу отриманих результатів. Тому питання підготовки якісного тесту - неабияк актуальне сьогодні.

Чи легко підготувати якісний тест? Виявляється, це не під силу без попередньої передтестової підготовки, що допомагає виявити в тесті ті завдання, які не відповідають поставленій меті, навіть кваліфікованим педагогам. Під час проведення нормативно-орієнтовного тесту основним його завданням є диференціація студентів за набраними балами. Як класична, так і сучасна теорія тестування дозволяє, використовуючи методи математично-статистичної обробки, виокремлювати ті тестові завдання, зміст яких потрібно корегувати, аби вони стали валідними (Крокер, Алгіна, 2010; Челишкова, 2002). Однак недостатнім є і виявлення непридатних для тестування завдань. Завдання, як правило, містять одну правильну відповідь та декілька дистракторів (від англ. distractor, distracter - відволікати) - неправильних, але правдоподібних відповідей. Тому наступним кроком повинен бути не лише аналіз змісту дистракторів, а й вибір найбільш ефективно діючих із них. Саме ігнорування необхідності проведення дистракторного аналізу є однією $з$ причин відсутності якісних тестів. Інша причина - незначна кількість публікацій за результатами дистракторного аналізу (Крокер, Алгіна, 2010; Челишкова, 2002), що і спонукало нас до написання означеної статті.

Аналіз наукових досліджень і публікацій. Наукові дослідження останніх років, в яких розглядається класична та сучасна теорія тестів, зокрема: підручник «Вступ до класичної та сучасної теорії тестів» (Л. Крокер, Дж. Алгіна, 2010); навчальний посібник «Теорія і практика конструювання педагогічних тестів» (М. Б. Челишкова, 2002); статті «3 досвіду математич- 
но-статистичної обробки результатів тестування та їх інтерпретація» (М. М. Козяр, В. В. Крівцов, О. В. Парфенюк, 2019), «3 досвіду укладання тестів з нарисної геометрії» (М. М. Козяр, В. В. Крівцов, 2019), «Статистичний аналіз тестів, що містять рисунки і без них» (М. М. Козяр, В. В. Крівцов, О. В. Парфенюк, В. В. Крівцов, 2019), «Аналіз результатів попереднього тестування для визначення якості завдань підсумкового контролю знань» (М. М. Козяр, В. В. Крівцов, В. В. Крівцов, 2020) та ін., свідчать, що для створення якісного тесту недостатньо виявити завдання, які підлягають корегуванню або вилученню. Передусім необхідно детально проаналізувати дистрактори, які є невід'ємною складовою всіх без винятку тестових завдань. Так, у дослідженні В. Ідіатуліна «Про дистриктори до тестових завдань» (2006) акцентується увага на тому, що зміст дистракторів повинен бути підібраний таким чином, щоб він не тільки сприяв дискримінативності тесту, а й допомагав виявляти в студентів прогалини в опануванні навчальним матеріалом, слугував внесенню коректив до дидактичного підходу викладання дисципліни. Крім того, зазначається, що важливою функцією аналізу змісту дистракторів $€$ те, що він допомагає викладачеві глибше вникнути в суть добре відомих положень навчальної дисципліни та спробувати уявити, як ті чи інші дистрактори сприймаються здобувачами освіти.

Мета статті - на конкретних прикладах продемонструвати, як проводиться дистракторний аналіз тестових завдань із метою виявлення ефективно діючих дистракторів, а також таких, які сприймаються більшістю учасників тестування, як неправдоподібні, а отже, потребують грунтовного доопрацювання.

Виклад основного матеріалу дослідження. Однією з причин появи неякісних тестових завдань $€$ відсутність дистракторного аналізу відповідей на завдання тесту. Якісно складений тест повинен містити ефективно діючі дистрактори. Дистрактор вважається ефективним, якщо його обирає більшість студентів із низьким рівнем знань, намагаючись вгадати правильну відповідь (Аванесов, 2012, с. 55-68; Аванесов, 2013). Такі дистрактори успішно виконують своє основне призначення - диференціюють студентів, які беруть участь у тестуванні, за рівнем знань. Тому зробити неправильні відповіді правдоподібними для студентів із поверховим уявленням про навчальний предмет є однією з основних вимог, що ставляться перед розробниками тестів. Із першого разу підготувати правдоподібні дистрактори не вдається навіть досвідченим педагогам, тому обов'язково потрібно проводити пробне тестування, яке дозволить підкорегувати або змінити зміст не лише дистракторів, а й по-іншому сформулювати завдання з правильною відповіддю (Крівцов Валерій, Крівцов Валентин, 2020, с. 155-157).

У представленій статті наведено методику, яку використовують автори для проведення дистракторного аналізу, що забезпечує диференціюючу здатність тестових завдань, тобто їхню дискримінативність. Для оцінки дискримінативності завдання використано два показники: показник розрізняльної здатності (показник дискримінативності) та кореляційний показник (точково-бісеріальний коефіцієнт).

Перший показник - показник дискримінативності $\left(D_{j}\right)$ - доволі простий у застосуванні. Якщо розробник тесту диференціює студентів, які тестуються, за набраним загальним балом за тест, то умовно визначаються дві групи студентів - відповідно із більш високими та низькими результатами. При цьому для аналізу результатів тестування відбирається не менше ніж 27\% студентів із кожної групи. Після визначення груп, протилежних за кількістю набраних балів, показник дискримінативності $D_{j}$ визначаємо за формулою:

$$
D_{j}=k_{j}^{1}-k_{j}^{2} \text {, де: }
$$

$k^{1}{ }_{j}$ - частка правильних відповідей на завдання для студентів, які тестуються, в групі з більш високими результатами;

$k^{2}$ - частка правильних відповідей на завдання для студентів із низькими результатами за тест (Крокер, Алгіна, 2010).

Значення $D$ можуть змінюватися від -1 до 1 . Якщо завдання правильно виконують більше кращих студентів, ніж тих, хто отримав гірші результати, то $D_{j}>0$; у протилежному випадку $D_{j}<0$. Якщо завдання правильно виконано однаковою кількістю відібраних студентів з обох груп, то $D_{j}=0$, тобто за цим значенням $D_{j}$ відповіді на завдання не дозволяють диференціювати студентів, які тестуються. У посібниках Л. Крокер, Дж. Алгіни та М. Челишкової наведено такі принципи для інтерпретації значень $D_{j}$ :

1. Якщо $D_{j} \geq 0.40$, то завдання виконує свою функцію задовільно.

2. Якщо $0.30 \leq D_{j} \leq 0.39$, то завдання потребує незначної корекції або в цьому немає потреби.

3. Якщо $0.20 \leq D_{j} \leq 0.29$, то завдання потребує перегляду

4. Якщо $D_{j} \leq 0.19$, то завдання необхідно замінити або взагалі виключити з тесту.

Другий показник - точково-бісеріальний коефіці$\epsilon$ нт $\left(r_{p b i s}\right)$ - оцінює кореляцію між результатами виконання кожного завдання та загальною кількістю балів за весь тест. Для дихотомічних тестів $r_{p b j}$ розраховують за формулою:

$$
r_{p b j s}=\frac{\left(\mu_{+}-\mu_{x}\right)}{\sigma_{x}} \sqrt{\rho / q}, \text { де: }
$$

$\mu_{+}-$середній бал тих студентів, які відповіли на j-е завдання тесту правильно;

$\mu_{x}$ - середній бал для всієї групи студентів, які тестуються;

$\sigma_{x}-$ середнє квадратичне відхилення балів, набраних студентами всієї групи;

$\rho_{j}-$ складність завдання, $q_{j}=1-p_{j}$.

Критичне значення точково-бісеріального коефіцієнта $\mathrm{r}_{\text {кр }}$, нижче якого не можуть опускатися значення гкр при відборі тестових завдань, залежить від кількості учасників тестування, тобто чим більше тих, хто бере участь у тестуванні, тим нижче $r_{\text {кр }}$, навпаки.

Аналізуючи згадані вище посібники Л. Крокер, Дж. Алгіни та М. Челишкової, можемо стверджувати, що завдання $3 \mathrm{r}_{\text {кр }}<0.2$ повинні бути вилучені з тесту, тоді як завдання $3 \mathrm{r}_{\text {кр }}>0.5$ найкраще диференціюють тих, хто бере участь у тестуванні.

У таблиці 1 наведено матрицю результатів пробного тестування $з$ тем «Пряма», «Площина», «Паралельність прямої та площини, двох площин» навчальної дисципліни «Нарисна геометрія». 
Матриця результатів пробного тестування

\begin{tabular}{|c|c|c|c|c|c|c|c|c|c|c|c|}
\hline \multirow{2}{*}{$\begin{array}{c}\text { Порядковий } \\
\text { номер } \\
\text { учасника } \\
\text { тестування }\end{array}$} & \multicolumn{10}{|c|}{ Завдання } & \multirow{2}{*}{$\begin{array}{c}\text { Індивідуальний } \\
\text { бал, } \mathbf{X}_{\mathbf{i}}\end{array}$} \\
\hline & 1 & 2 & 3 & 4 & 5 & 6 & 7 & 8 & 9 & 10 & \\
\hline $1^{*}$ & 1 & 1 & 1 & 1 & 1 & 1 & 1 & 1 & 0 & 0 & 8 \\
\hline $2^{(-)}$ & 1 & 1 & 0 & 0 & 0 & 0 & 0 & 0 & 0 & 0 & 2 \\
\hline $3^{(-)}$ & 0 & 0 & 0 & 0 & 0 & 0 & 0 & 1 & 0 & 0 & 1 \\
\hline $4 *$ & 1 & 1 & 0 & 1 & 1 & 1 & 1 & 1 & 1 & 1 & 9 \\
\hline $5^{(-)}$ & 1 & 0 & 0 & 0 & 1 & 1 & 0 & 0 & 0 & 0 & 3 \\
\hline $6^{(-)}$ & 1 & 1 & 1 & 0 & 0 & 0 & 0 & 0 & 0 & 0 & 3 \\
\hline $7^{(-)}$ & 1 & 1 & 1 & 0 & 0 & 0 & 0 & 0 & 0 & 0 & 3 \\
\hline 8 & 1 & 1 & 1 & 1 & 0 & 0 & 0 & 0 & 0 & 0 & 4 \\
\hline $9^{*}$ & 1 & 1 & 1 & 1 & 1 & 1 & 1 & 1 & 0 & 0 & 8 \\
\hline $10 *$ & 1 & 1 & 1 & 1 & 1 & 1 & 1 & 0 & 0 & 0 & 7 \\
\hline 11 & 1 & 0 & 1 & 0 & 0 & 1 & 1 & 0 & 0 & 1 & 5 \\
\hline 12 & 0 & 0 & 1 & 1 & 1 & 1 & 0 & 0 & 1 & 0 & 5 \\
\hline $13 *$ & 1 & 1 & 1 & 1 & 1 & 1 & 0 & 0 & 0 & 1 & 7 \\
\hline 14 & 1 & 1 & 0 & 1 & 1 & 1 & 0 & 0 & 1 & 0 & 6 \\
\hline 15 & 1 & 1 & 0 & 1 & 1 & 1 & 1 & 0 & 0 & 0 & 6 \\
\hline$R_{j}$ & 13 & 11 & 9 & 9 & 9 & 10 & 6 & 4 & 3 & 3 & $\sum 77$ \\
\hline$p_{j}$ & 0.87 & 0.73 & 0.6 & 0.6 & 0.6 & 0.67 & 0.4 & 0.27 & 0.2 & 0.2 & \\
\hline$q_{j}$ & 0.13 & 0.27 & 0.4 & 0.4 & 0.4 & 0.33 & 0.6 & 0.73 & 0.8 & 0.8 & \\
\hline$D_{j}$ & 0.2 & 0.4 & 0.4 & 1 & 0.8 & 0.8 & 0.8 & 0.4 & 0.2 & 0.4 & \\
\hline$r_{p b j}$ & 0.39 & 0.44 & 0.24 & 0.82 & 0.76 & 0.79 & 0.71 & 0.24 & 0.34 & 0.41 & \\
\hline
\end{tabular}

Відповідно $R_{j}$ - сума балів, набраних студентами всієї групи, за виконання ј-го завдання або, враховуючи дихотомічне оцінювання тесту, $R_{j}$ чисельно дорівнює кількості студентів, які виконали ј-е завдання тесту правильно; $p_{j}=R / n$, де $n$ - кількість тих, хто підлягає тестуванню $(\mathrm{n}=15)$. У тестуванні беруть участь дві групи студентів (по 5 осіб у кожній) відповідно з кращими та гіршими результатами за наслідками тестування. Групу 3 високим результатом тестування позначено знаком «*», тоді як групу з низьким результатом - знаком «(-)».

Наведемо обчислення $D_{j}$ тa $_{\mathrm{pbjs}}$ за формулами $(1),(2)$ для 1 завдання:

$D_{1}=5 / 5-4 / 5=1-0.8=0.2$;

$\mu_{+}=\frac{8+2+9+3+3+3+4+8+7+5+7+6+6}{13}=\frac{71}{13}=5.46$;

$\mu_{x}=\frac{\sum x_{i}}{n}=\frac{77}{15}=5.1$;

$\sigma_{x}{ }^{2}=\frac{\sum_{i}^{n}{ }_{i} f_{i}\left(X_{i}-\mu_{x}\right)^{2}}{n}=$

$(9-5.1)^{2}+2(8-5.1)^{2}+2(7-5.1)^{2}+2(6-5.1)^{2}+$

$+2(5-5.1)^{2}+(4-5.1)^{2}+3(3-5.1)^{2}+(2-5.1)^{2}+$

$+(1-5.1)^{2}$

$/ 15=5.45, \sigma_{x}=2.33, p_{j}=13 / 15=0.87, q_{j}=1-p_{j}=$

$=1-0.87=0.13$, тоді $r_{p b l s}=\frac{(5.46-5.1)}{2.33} \sqrt{\frac{0.87}{0.13}}=0.39$.
Аналіз завдань за показниками $D_{j}$ та $\mathrm{r}_{\mathrm{pbjs}}$ свідчить, що оптимальними є завдання з 4 до 7. Як стверджують Л. Крокер, Дж. Алгіна та М. Челишкова, оптимальними вважаються такі завдання тесту, де відсоток тих, хто тестується, які відповіли неправильно, приблизно рівномірно розподілений між дистракторами, що пропонуються.

Детальніше розглянемо зміст завдань, які підлягають корегуванню. Для цього скористаємося таблицею 2, де наведено кількісний розподіл між тими, хто тестується, які обрали одну правильну (позначено знаком «*») й відповідно - три неправильні відповіді (позначено знаком «(-)») із чотирьох запропонованих.

У завданні №1 двоє студентів як правильну обрали відповідь 4, яка є дистрактором, а відповіді 1 та 2 не обрав жоден студент. Схвально, що більшість учасників тестування обрали відповідь 3 , яка є правильною. Розглянемо зміст запропонованих завдань.

Завдання № 1. Вербальна частина: «На якому з рисунків (рис. A-D) правильно визначено натуральну величину (далі-Н.В.) відрізка АВ прямої загального положення?». Графічну частину завдання наведено на рис. 1. 
Розподіл відповідей між учасниками тестування

\begin{tabular}{|c|c|c|c|c|c|c|c|c|c|}
\hline \multirow{2}{*}{ Завдання } & \multicolumn{4}{|c|}{$\begin{array}{c}\text { Розподіл відповідей } \\
\text { між учасниками тестування }\end{array}$} & \multirow{2}{*}{ Завдання } & \multicolumn{4}{|c|}{$\begin{array}{c}\text { Розподіл відповідей } \\
\text { між учасниками тестування }\end{array}$} \\
\hline & 1 & 2 & 3 & 4 & & 1 & 2 & 3 & 4 \\
\hline 1 & 0 & 0 & $13^{*}$ & 2 & 6 & $10 *$ & 2 & 2 & 1 \\
\hline 2 & $11^{*}$ & 3 & 1 & 0 & 7 & 3 & 3 & $6^{*}$ & 3 \\
\hline 3 & 1 & $9 *$ & 3 & 3 & 8 & 5 & $4 *$ & 3 & 1 \\
\hline 4 & 2 & 2 & $9 *$ & 2 & 9 & 4 & 5 & 1 & $3 *$ \\
\hline 5 & 2 & 2 & 2 & $9 *$ & 10 & 1 & 4 & 5 & $3 *$ \\
\hline
\end{tabular}

Рисунки $A-D$ розміщені відповідно до відповідей $1-4$, зазначених у таблищчі 2 , тобто рис. $C$ відповідає правильній відповіді під № 3. На puc. $A$ та puc. $Б$ зображено невдало підібрані, тобто неправдоподібні, дистрактори, які потрібно замінити, оскільки навіть недостатньо підготовлені студенти знають, що при визначенні Н.В. вибирають $\Delta_{y}$ або $\Delta_{z}$ на одній з проєкцій відрізка прямої, а відкладають на іншій проєкції. На puc. $D$ подано привабливий дистрактор, оскільки $\Delta_{\text {у }}$ иббрано на площині $\pi_{1}$, а відкладено на площині $\pi_{2}$.

Як правильний рис. С обрали більшість учасників тестування, оскільки він поданий у своїй традиційній формі для визначення Н.В., яка і закарбувалася в пам'яті студентів. Форму подання рис. $C$ потрібно змінити на менш очевидну, наприклад, замість « $\Delta \mathrm{z}\rangle$ використати інше позначення або відкласти відрізок, позначений « $\Delta \mathrm{z} »$, у бік осі $x$, а не так, як зазвичай виконується.

Завдання № 2. Вербальна частина: «На якому 3 рисунків (рис. $A-D)$ правильно зображено точку $A$, щчо належить площині $\alpha$ ?». Графічну частину завдання наведено на рис. 2.

Дистрактори (відповіді 3 і 4) потрібно замінити, оскільки зображені на рuс. $C$ i puc. $D$ прямі $l$ студенти явно сприймають як такі, що не належать площині $\alpha$, тобто самі дистрактори, очевидно, є неправильними навіть для слабо підготовлених студентів. Крім того, правильну відповідь 1 потрібно ускладнити, наприклад, задавши площину не слідами, а трикутником.

Завдання № 3. Вербальна частина: "На якому з рисунків (рис. A-D) пряма l належить площині?». Графічну частину завдання наведено на рис. 3.
Дистрактор (відповідь 1) потрібно замінити, оскільки студенти пряму $l$ відразу ідентифікують як таку, що не належить площині. Слід зазначити, що і пряму $l$, зображену на рис. $C$ із завдання № 2 , також не сприймають як пряму, що належить площині. Дистрактори (відповіді 3 і 4) слід залишити, оскільки слабо підготовлені студенти сприймають їх як правдоподібні, забуваючи при цьому правило, що точка належить прямій, якщо однойменні проєкції точки знаходяться на однойменних проєкціях прямої.

Розглянемо завдання, які також мають низьку дискримінативність і де більшість учасників тестування як правильні відповіді обрали саме дистрактори.

Завдання №8. Вербальна частина: «На якому з рисунків (рис. A-D) пряма l паралельна до площини?». Графічну частину завдання наведено на рис. 4.

Правильну відповідь обрали лише четверо учасників тестування. Складність завдання полягала в тому, що площина $\alpha$ - це горизонтально-проєкціююча площина, яка задана тільки однією прямою, своїм слідом-проєкцією. Студентам важко зрозуміти, якщо $l, / / \alpha$, то пряма $l$ буде паралельною до $\alpha$ незалежно від того, яким чином буде розміщена фронтальна проєкція прямої $l_{2}$.

На думку авторів, цю відповідь у тесті варто залишити. Проте у майбутньому, спираючись на проведений аналіз, під час вивчення паралельності прямої та площини пояснити, що в площині $\alpha$ можна провести довільну пряму $в$, в якої $\theta_{1} \equiv \alpha_{l}$, тобто $\varepsilon_{l} / / l_{l}$, а $\varepsilon_{l} / / l_{l}$. Відповідь 1 містить привабливий дистрактор, як і відповідь 3 . Проте дистрактор, що міститься у відповіді 4, потрібно замінити, оскільки лише один студент обрав його за правдоподібний.

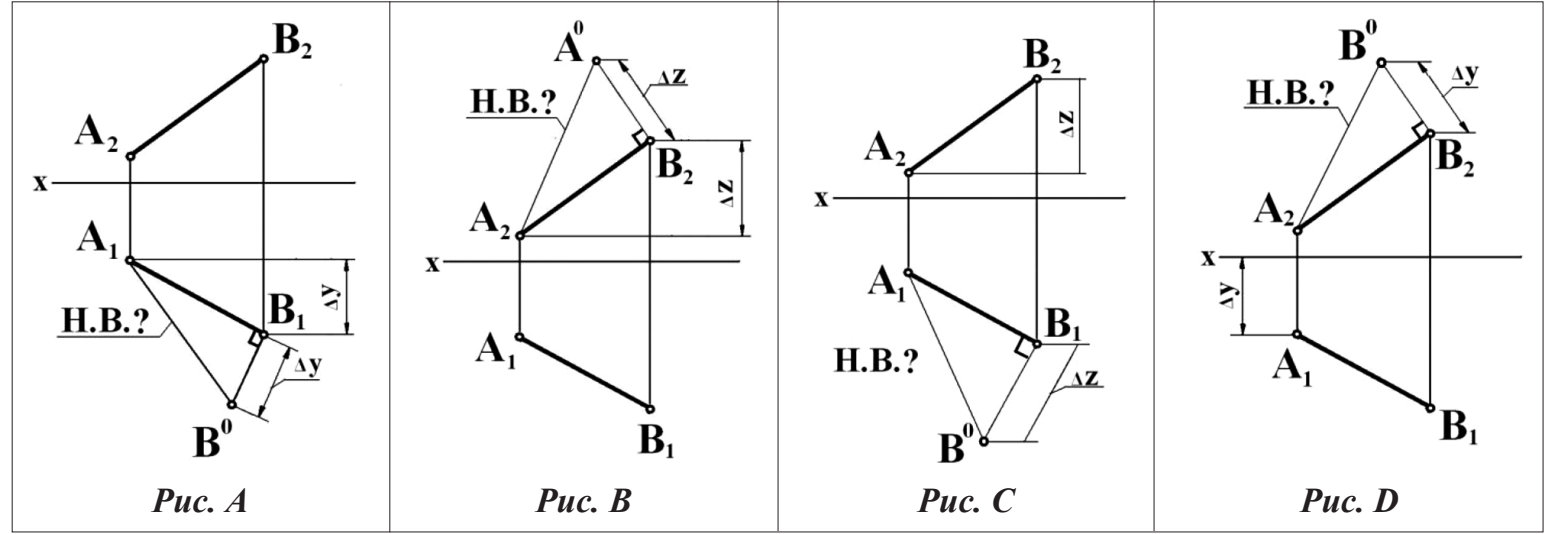

Рис. 1. Графічна частина завдання № 1 


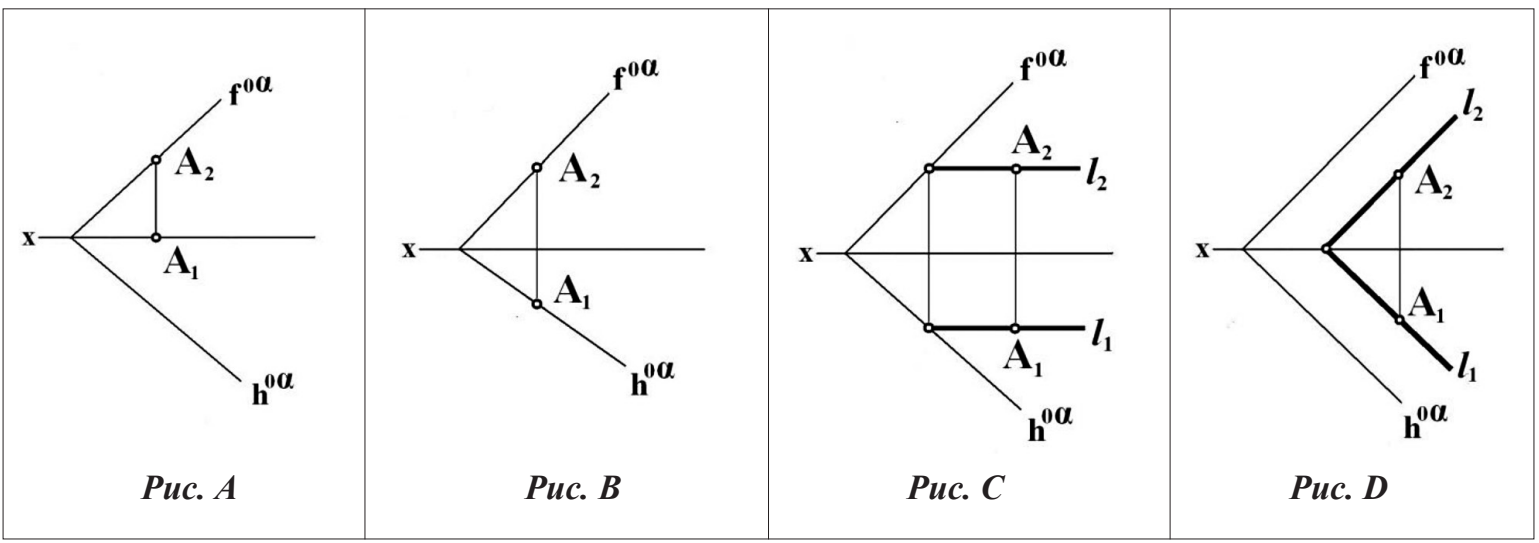

Рис. 2. Графічна частина завдання № 2

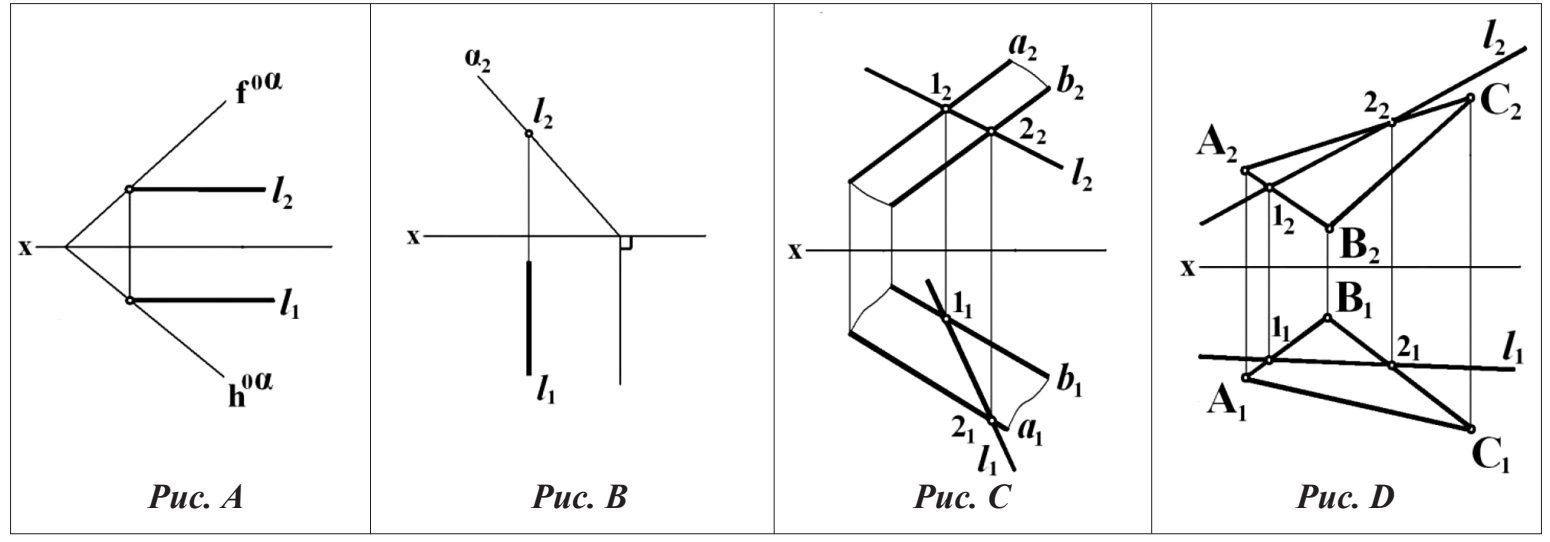

Рис. 3. Графічна частина завдання №3

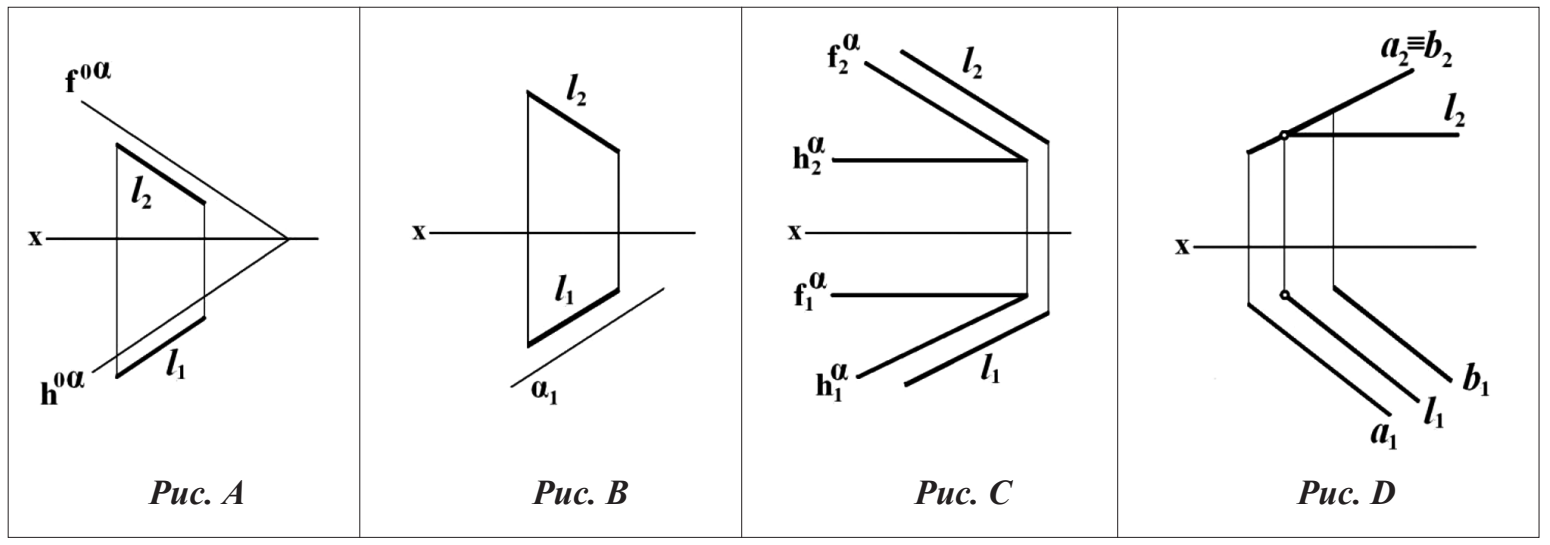

Рис. 4. Графічна частина завдання № 8

Завдання № 9. Вербальна частина: «На якому з рисунків (рис. A-D) зображено дві паралельні площини?». Графічну частину завдання наведено на рис. 5.

Дистрактори (puc. A, puc. Б) виявилися надто привабливими для студентів. До вибору цих дистракторів як правильних відповідей їх спонукав той факт, що $\mathrm{A}_{2} \mathrm{C}_{2} / / \alpha_{2}$ (puc. A) і $\beta_{2} / / \mathrm{f}^{0 \alpha}$ (puc. Б), тобто сама форма подання графічної частини вплинула на вибір студентів більше ніж обов'язковий перед прийняттям рішення аналіз елементів, що входять до умови задачі. Якби цей аналіз був проведений, то можна було б з'ясувати, що на puc. $A$ та $p u c . Б$ зображено дві площини, де одна $\epsilon$ проєкціюючою, а інша - загального положення. А такі площини апріорі не можуть бути паралельними, навіть без залучення до аналізу визначення паралельності двох площин: дві площини паралельні, якщо дві прямі, що перетинаються, однієї площини паралельні до двох прямих, що перетинаються, другої площини. Ці дистрактори потрібно залишити у завданні, оскільки вони допомагають диференціювати студентів за рівнем знань.

Перевагу відповіді 4, яка є правильною, надали лише троє студентів. Помилилися у цьому виборі навіть ті студенти, які набрали високий сумарний бал. Аналіз рис. D свідчить, що задані площини є фронтально-проєкціюючими, в яких сліди-проєкції паралельні, а отже, і самі площини є паралельними. На запитання «Чому як правильну відповідь ви не обрали рис. D?», студенти відповіли, що їх заплутав той факт, що горизонтальні проєкції прямих двох площин непаралельні між собою. Такі відповіді студентів повинні спонукати 


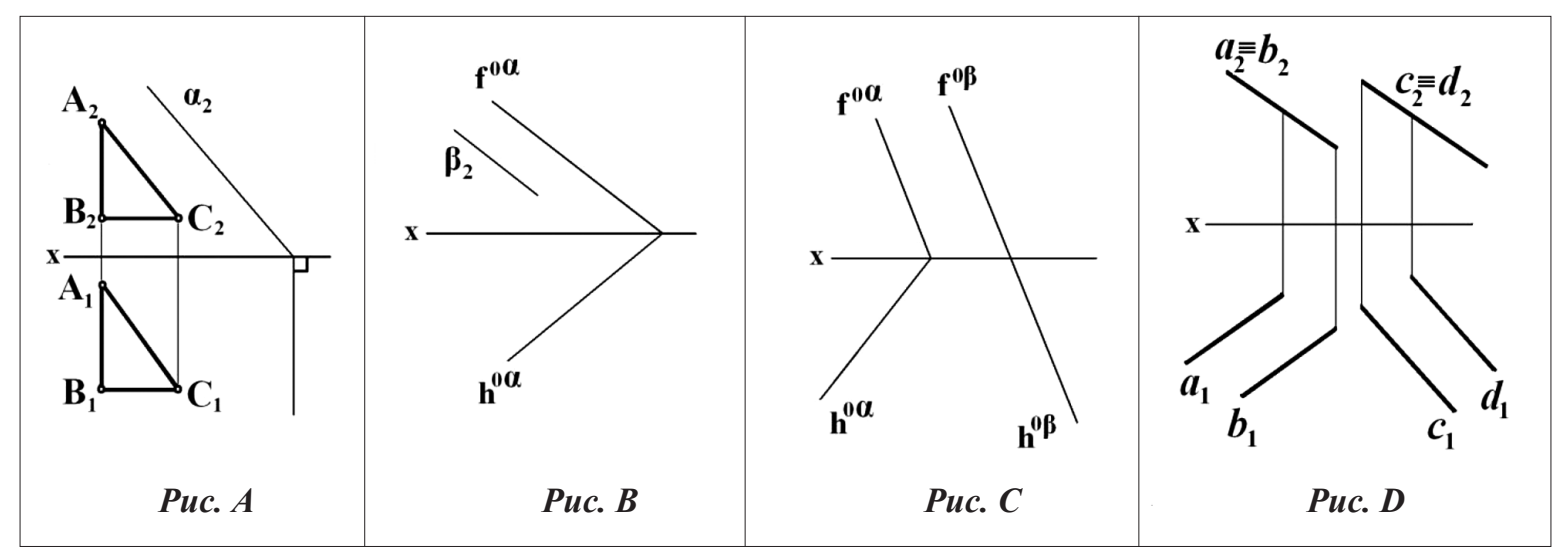

Рис. 5. Графічна частина завдання № 9

викладачів здійснювати під час лекцій та практичних занять більш грунтовний аналіз геометричних елементів, що входять до умови завдання, детально розбиратися, як вони розміщені в просторі один відносно іншого. Дистрактор (рис. С) виявився для студентів очевидно неправильним, хоча авторам здавалося, що серед інших дистракторів він буде найбільш привабливим, оскільки на puc. $C$ зображено дві площини загального положення, в яких фронтальні сліди паралельні. Проте для студентів той факт, що горизонтальні сліди площин непаралельні, виявився вирішальним в ідентифікації цієї відповіді як неправильної. Даний дистрактор варто замінити на менш очевидний.

Зауваження, наведені до завдання № 9, стосуються і завдання № 10, зміст якого також потрібно корегувати.

Висновки. Зважаючи на викладене вище, зазначимо, що для отримання якісного тесту обов'язково слід проводити пробне тестування з метою виявлення тих завдань, які потребують корегування. Наступним етапом удосконалення тесту є аналіз змісту завдань, які складаються з правильних відповідей та дистракторів. Такий аналіз дозволить залишити лише ефективно діючі дистрактори, а умову правильної відповіді представити таким чином, щоб з їі допомогою не тільки контролювалися знання, а й у процесі тестування відбувалося більш грунтовне опанування учасниками тестування положень навчальної дисципліни.

Подальші наші дослідження плануємо присвятити розробці таких дистракторів, відхилення яких як неправильних відбувалося б не за їхніми зовнішніми ознаками, а у зв'язку з аналітичною розумовою діяльністю тих, хто проходитиме тестування, що грунтується на знаннях теоретичних положень навчальної дисципліни.

\section{СПИСОК ВИКОРИСТАНОЇ ЛІТЕРАТУРИ}

Крокер Л., Алгина Дж. (2010). Введение в классическую и современную теорию тестов: учебник / пер. с англ.; под. общей ред. В. И. Звоникова, М. Б. Челышковой. Москва: Логос. 668 с.

Челышкова М. Б. (2002). Теория и практика конструирования педагогических тестов: учебное пособие. Москва: Логос. 432 с.

Козяр М., Крівцов В., Парфенюк О. (2019). 3 досвіду математично-статистичної обробки результатів тестування та їх інтерпретація. Науковий вісник Миколаӥвського національного університету імені В. О. Сухомлинського. Педагогічні науки: зб. наук. праць. № 1 (64). Лютий. С. 118-125.

Козяр М. М., Крівцов В. В. (2019). 3 досвіду укладання тестів 3 нарисної геометрії. Інноваційна педагогіка. Вип. 10. Т. 2. С. 105-110.

Козяр М. М., Крівцов В. В., Парфенюк О. В., Крівцов В. В. (2019). Статистичний аналіз тестів, що містять рисунки і без них. Науковий часопис Національного педагогічного університету імені М. П. Драгоманова. Серія 5 «Педагогічні науки: реалії та перспективи»: зб. наук. праць. 2019. Вип. 72. Т. 1. Київ: Вид-во НПУ імені М. П. Драгоманова. С. 230-237.

Козяр М. М., Крівцов В. В., Крівцов В. В. (2020). Аналіз результатів попереднього тестування для визначення якості завдань підсумкового контролю знань. Украӥнський психолого-педагогічний науковий збірник. № 19 (19). Квітень. С. 34-43.

Идиатулин В. (2006). О дистракторах к тестовым заданиям. Педагогические измерения. № 2. С. 64-84.

Аванесов В. (2013). Дистракторный анализ. Viperson. Ru: сайт. URL: http://viperson.ru/articles/ distraktornyy-analiz (дата звернення: 16.11.2020).

Аванесов В. С. (2012). Критерии качества педагогических измерений. Педагогические измерения. № 1. C. $55-68$.

Крівцов Валерій, Крівцов Валентин. (2020). Проведення пробного тестування для аналізу дистракторів. Інноваиійні технології розвитку машинобудування та ефективного функиіонування транспортних систем: збірник тез II Міжнародної наук.-техн. конференції (м. Рівне, 25-27 березня 2020 р.) / Національний університет водного господарства та природокористування. Рівне. С. $155-157$.

\section{REFERENCES}

Kroker, 1. and Algina, Dzh. (2010). Vvedenie v klassicheskuyu I sovremennuyu teoriyu testov [Introduction to classical and modern test theory]: uchebnyk/ per. s anhl.; pod. obshchei red. V. Y. Zvonykova, M. B. Chelyshkova. Moskva: Lohos. 668 s. [in Russian].

Chelyshkova, M. B. (2002). Teoriya i praktika konstruirovaniya pedagogicheskikh testov: uchebnnoe posobye. [Theory and practice of constructing pedagogical tests]Moskva: Logos. 432 s. [in Russian].

Koziar, M., Krivtsov, V., Parfeniuk, O. (2019). Z dosvidu matematychno-statystychnoi obrobky rezultativ testuvannia ta yikh interpretatsiia [From the experience of mathematical and 
statistical processing of test results and their interpretation]. Naukovyi visnyk Mykolaivskoho natsionalnoho universytetu imeni V. O. Sukhomlynskoho. Pedahohichni nauky: zb. nauk. pr. № 1 (64). February. S. 118-125. [in Ukrainian].

Koziar, M. M., Krivtsov, V. V. (2019). Z dosvidu ukladannia testiv $\mathrm{z}$ narysnoi heometrii [From the experience of writing tests in descriptive geometry]. Innovatsiina pedahohika. Vyp. 10. T. 2. S. 105-110. [in Ukrainian].

Koziar, M.M., Krivtsov, V.V., Parfeniuk, O.V., Krivtsov, V.V. (2019). Statystychnyi analiz testiv, shcho mistiat rysunky i bez nykh [Statistical analysis of tests that contain pictures and without them]. Naukovyi chasopys Natsionalnoho pedahohichnoho universytetu imeni M. P. Drahomanova. Seriia 5 «Pedahohichni nauky: realii ta perspektyvy»: zb. nauk. prats. Kyiv: Vyd-vo NPU imeni M. P. Drahomanova, Vyp. 72. T. 1. S. 230-237. [in Ukrainian].

Koziar, M. M., Krivtsov, V. V., Krivtsov, V. V. (2020). Analiz rezultativ poperednoho testuvannia dlia vyznachennia yakosti zavdan pidsumkovoho kontroliu znan [Analysis of the results of preliminary testing to determine the quality of the tasks of the final control of knowledge]. Ukrainskyi psykholoho-pedahohichnyi naukovyi zbirnyk. № 19 (19). Kviten. S. 34-43. [in Ukrainian].

УДК 373.53:37.016:91

DOI: 10.37026/2520-6427-2021-105-1-42-48
Idiatulin, V. (2006). O distraktorakh k testovym zadaniyam [About distractors for test tasks ]. Pedagogicheskie izmereniya. № 3. S. 64-84. [in Russian].

Avanesov, V. Distraktornyj analiz [Distractor analysis]. Viperson. Ru: site. URL: http://viperson.ru/articles/distraktornyy-analiz (data zvernennia: 16.11.2020). [in Russian].

Avanesov, V. S. (2012). Kriterii kachestva pedagogicheskikh izmerenij [Quality criteria for pedagogical measurements]. Pedagogicheskie izmereniya. № 1. S. 55-68. [in Russian].

Krivtsov Valerii, Krivtsov Valentyn. (2020). Provedennia probnoho testuvannia dlia analizu dystraktoriv [Proof testing for distractor analysis]. Innovatsiini tekhnolohii rozvytku mashynobuduvannia ta efektyvnoho funktsionuvannia transportnykh system: zbirnyk tez II Mizhnarodnoi nauk.-tekhn. konferentsii (Rivne, 25-27 bereznia 2020 r.) / Natsionalnyi universytet vodnoho hospodarstva ta pryrodokorystuvannia. Rivne. S. 155-157. [in Ukrainian].

Дата надходження до редакиії 08.02.2021 p

Григорій ПУСТОВІТ,

доктор педагогічних наук, професор,

професор кафедри природничо-математичної освіти Рівненського обласного інституту післядипломної педагогічної освіти, м. Рівне, Україна

ORCID: 0000-0001-7754-0249,

e-mail:h.pustovit@gmail.com

Ярослав СИВОХОП,

кандидат педагогічних наук, доиент, директор Закарпатського інституту післядипломної педагогічної освіти, м. Ужггород, Україна

ORCID: 0000-0003-1651-8368

e-mail: suvochop@ukr.net

\section{УПРОВАДЖЕННЯ МТЕМ-ОСВІТИ НА УРОКАХ ГЕОГРАФПЇ: СПРЯМОВАНІСТЬ НА САМОСТІЙНИЙ ТВОРЧИЙ РОЗВИТОК ДИТИНИ*}

\begin{abstract}
Анотація. У статті схарактеризовано сутнісні ознаки дидактичної складової упровадження STEM-освіти в сучасних закладах загальної середньої освіти, зокрема на уроках географії. Метою ї̈ запровадження $\epsilon$ гармонійний розвиток особистості завдяки формуванню провідних життєво важливих компетентностей, природничо-наукової картини світу, світоглядних позицій $i$ життєвих иінностей. Виокремлено й частково розкрито нормативну основу та значення иього підходу у розвитку освітнього простору держави як провідної складовоі державної політики з підвищення рівня конкурентоспроможності начіональної системи освіти. Схарактеризовано теоретико-прикладний аспект провідних наукових
\end{abstract}

підходів функиіонування STEM-освіти: мультидисииплінарного, плюридисциплінарного, інтердисииплінарного, трансдисциплінарного. У межах останнього підходу актуальними залишаються традииійні дидактичні наукові підходи до побудови навчального змісту за умови їх орієнтаиії, передусім, на активну самостійну і творчу діяльність, шчо є провідною у прочесах навчання та формування в учнів умінь і навичок самоосвіти, котрі $\epsilon$ ключовими в переліку провідних життєвих $і$ кар'єрних «Навичок XXI століття». Такими традиційними дидактичними підходами до конструювання навчального змісту і самостійної діяльності учнів є: міжпредметний, інтеграчійний, диферениіачиї та індивідуалізації.

* Продовження. Початок у № 4 (104) за 2020 р. 